\title{
MILLAL SURI AIN RANNALEET?
}

Ain Rannaleedi (kodanikunimega Rudolf Laurent), Venemaal elanud eesti luuletaja ja prosaisti saatuse kohta on paberkandjal teatmeteostes ja veebientsüklopeedias Vikipeedia kirjutatud, et ta arreteeriti 1937. aastal ja suri 13. septembril 1943 vangilaagris. Surmakohta pole seni kusagil mainitud. On aeg see nõukogude võimuorganite tahtlik väärinformatsioon kummutada ja lisada mõned faktid.

Seni värskeimas allikas, 1998. aastal Peterburis ilmunud teose „Денинградский мартиролог: 1937-1938” 3. köite lk 233 on kirjas:

Laurent, Rudolf Juhani poeg, sündinud 1904 Simititsa külas Volossovi rajoonis Leningradi oblastis, eestlane, parteitu, Duderhofi Soome Mittetäieliku Keskkooli õpetaja, elas: Leningrad, Kaznatšejevskaja t 7 krt 35. Arreteeriti 28. augustil 1937. aastal. NKVD ja NSV Liidu Prokuratuuri Komisjoni poolt Vene NFSV kriminaalkoodeksi \$ 58-1a alusel mõistetud kõrgeim karistusmäär. Maha lastud 11. novembril 1937 Leningradis.

Sama teabe leiab veebiaadressilt: http://visz.nlr.ru/search/lists/t3/235_1. html

Nooremale lugejaskonnale teadmiseks: tegemist oli poliitilise paragrahviga Vene NFSV kriminaalkoodeksis, mis 1940. aastal kehtestati ka okupeeritud Eestis. Selle alusel võeti elu tuhandetelt eestlastelt.
Mul on hüpotees selle kohta, kuidas taoline valeinfo meie kirjasõnasse sattus. Kui 1950. aastatel hakati soodustama eesti nn proletaarsete kirjanike elulugude ja loomingu uurimist, siis tollased julgeolekuorganid Ain Rannaleedi õiget surmakuupäeva, -kohta ega -põhjust kirjandusteadlastele ei avaldanud, vaid andsid väljamõeldud kuupäeva. Sama juhtus tollal muide minu Elvas elanud vanatädiga, kes esitas KGB-le avalduse, et teada saada mu 14. juunil 1941. aastal küüditatud ja Siberis maha lastud vanaisa saatust. Vanatädi kutsuti välja ja talle anti suuliselt nii väljamõeldud kuupäev kui ka laest võetud surmapõhjus. Aastaid hiljem, ikka veel nõukogude ajal väljastatud surmatunnistusel oli küll õige kuupäev, aga surmapõhjuse kohal seisis kriips.

1937. aastal Leningradis ja Leningradi oblastis elanud hukatutest olid arvuliselt rahvuste lõikes esikohal venelased, siis poolakad. Neile järgnesid... jah, suurrahvastele järgnes pisirahvas eestlased: 832 meest ja 54 naist, kokku 886 bolševikelt kuuli saanud kaasmaalast seda vaid ühe aasta jooksul ainult ühes tohutu suure NSV Liidu piirkondadest. Mahalaskmised tipnesid 20. detsembril 1937, NKVD 20. aastapäeval, kui ühe päevaga mõrvati ainuüksi Leningradis 90 eestlast.

Niisiis suri Ain Rannaleet 11. novembril 1937 Leningradis.

UNO SCHULTZ 